\title{
Density dynamics of Notholca squamula salina Focke (Rotifera) in Lake Wujka, a freshwater Antarctic lake
}

\author{
Agnieszka Pociecha
}

Received: 6 June 2007/Revised: 7 August 2007 / Accepted: 8 August 2007/Published online: 5 September 2007

(C) Springer-Verlag 2007

\begin{abstract}
The Antarctic Lake Wujka $\left(62^{\circ} 09^{\prime} 28.3^{\prime \prime} \mathrm{S}\right.$, $\left.58^{\circ} 27^{\prime} 56.3^{\prime \prime} \mathrm{W}\right)$, a shallow water body $\left(Z_{m}=1.38 \mathrm{~m}\right)$, situated at c. $15 \mathrm{~m}$ from the seashore was sampled at two points (Sp 1 and Sp 2) at 3-day intervals from December 2003 to June 2004. The two sampling points differing in location and depth: $\mathrm{Sp} 1\left(Z_{m}=0.50 \mathrm{~m}\right)$ was the shallowest site, located near the lake outlet, while $\operatorname{Sp} 2\left(Z_{m}=1.38 \mathrm{~m}\right)$ was the deepest spot of the lake. The population density of Notholca squamula salina peaked in June (at 114 ind. $1^{-1}$ ) at Sp 1, while at Sp 2 peaked in January $\left(80\right.$ ind. $\mathrm{l}^{-1}$ ) and May (150 ind. $\left.1^{-1}\right)$. Spearman non-parametric correlations with temperature, salinity, total dissolved solids, conductivity and $\mathrm{pH}$ revealed effects that characterize $N$. squamula salina as a species capable of surviving in a range of aquatic environments, but with a preference for high salinity, food and low temperature. It occurred in highest numbers when the diatom Achnanthes lanceolata var. rostrata (Øestrup) Hust., normally a benthic species, was stirred up into the water during storms that also raised the lake's salinity to above $20 \mathrm{psu}$.
\end{abstract}

Keywords Notholca squamula salina .

Environmental factors · Freshwater lake · Salinity ·

Antarctica $\cdot$ Rotifers

\footnotetext{
A. Pociecha $(\bowtie)$

Institute of Nature Conservation, Department of Freshwater Biology, Polish Academy of Science, A. Mickiewicz Av. 33, 31-120 Kraków, Poland

e-mail: pociecha@iop.krakow.pl

A. Pociecha

Department of Antarctic Biology, Polish Academy of Science, Ustrzycka 10/12, 02-141 Warsaw, Poland
}

\section{Introduction}

Antarctic lakes are characterized by very short food chains and it is noticeable that there is very limited species diversity amongst the micro-invertebrates (16-17 species of rotifer) (McInnes and Ellis-Evans 1990). In those lakes, planktonic communities are dominated by microorganisms, mostly bacteria, protists and metazooplankton. Metazooplankton is usually represented by rotifers and calanoid copepods (mainly from the genus Boeckella) (Comacho 2006).

Cosmopolitan rotifers inhabit diverse environments and ecological, rather than geographical, barriers control their distribution (Pejler 1995).

Representatives of the genus Notholca are common in Antarctic lakes. Early Holocene sediments from such a lake (Ace Lake, Vestfold Hills, East Antarctica) include fossils of Notholca resembling the species present in the region today (Swadling et al. 2001). One of these, Notholca squamula salina Focke, inhabits some of the most hostile environments on earth, Antarctic pools and lakes (Dartnall 1983; Dartnall and Hollowday 1985; Janiec 1993, 1996).

One of the objectives of the 28th (2003-2004) Polish Academy of Sciences' Antarctic expedition to the Henryk Arctowski Antarctic station was to study the N. squamula salina inhabiting one of the station's freshwaters, Lake Wujka. This lake is interesting for field experimentation because it is subject to rapid salinity changes. The high waves that rise during a storm bring seawater into the lake. The salinity of lake water may increase from almost 0 to $24 \mathrm{psu}$, while its water temperature is decreased to $-1.0^{\circ} \mathrm{C}$ (Pociecha, unpublished data).

Here, I provide a characterization of the changes in density of the $N$. squamula salina population living in this changeable habitat. My aim was to determine how ambient 
physical-chemical variables affect the dynamics of this rotifer, and whether this effect is sampling-point dependent.

\section{Study area}

King George is the largest island of the South Shetland archipelago, with a total area of $1,312 \mathrm{~km}^{2}$. It is composed of volcanic rock and is $90 \%$ ice covered (Rakusa-Suszczewski 1992). The study was carried out in freshwater Lake Wujka $\left(62^{\circ} 09^{\prime} 28.3^{\prime \prime}, 58^{\circ} 27^{\prime} 56.3^{\prime \prime}\right.$, surface area $800 \mathrm{~m}^{2}$ ), located on the site of the Henryk Arctowski Polish Antarctic station (Fig. 1).

This lake is shallow, with a maximum depth of $1.38 \mathrm{~m}$, situated on a marine beach behind a storm ridge, and regularly receives wind-blown seawater. It is ice-free for 7 months and freezes solid in winter. The bottom is composed of muddy sediment (20-40 cm thick), $5-20 \%$ of which is covered with filamentous green algae (Janiec 1993). Its main water supply is a nearby glacier and the socalled Moss Creek (Potok Mchowy, in Polish). During violent storms, seawater breaches the lake and temporarily renders it saline (up to $24.3 \mathrm{psu}$ ). The lake flushes back to the sea during spring and fall, as well as sometimes in winter.

Phytoplankton is represented by 14 diatom genera: Achnanthes; Amphora; Caloneis; Cymatopleura; Cymbella; Diatoma; Fragilaria; Gomphonema; Hantzschia, Navicula; Nitzschia; Pinnularia; Stauroneis and Surirella. The most abundant of these are Achnanthes (49.7\% of total diatom community), Pinnularia (15.6\%), Stauroneis (7.2\%), Navicula (7.1\%), Nitzschia (6.6\%), and Fragilaria
(5.8\%), with Achnanthes lanceolata var. rostrata (Øestrup) Hust. the commonest (Ochwanowski and Pociecha 2005).

A year-long investigation yielded five species of rotifers, viz. Notholca squamula salina Focke, 1961; N. walterkostei José De Paggi, 1982; Epiphanes senta (O.F.Müller, 1773); Lepadella patella (Müller, 1773); Cephalodella catellina (O.F.Müller, 1786), as well as a non-identified Bdelloid. Two crustacean species detected were Branchinecta gaini Daday, 1910 and Boeckella poppei Mrazek, 1901 (Janiec 1996; Pociecha 2005).

\section{Materials and methods}

Rotifers were sampled at three-day intervals between December 2003 and June 2004, at two points differing in location and depth: Sp $1\left(Z_{m}=0.50 \mathrm{~m}\right)$ was the shallowest site, located near the lake outlet, while $\mathrm{Sp} 2$ $\left(Z_{m}=1.38 \mathrm{~m}\right)$ was the deepest spot of the lake. Rotifer samples for quantitative analyses were collected using a 31 sampler. Samples were filtered through a plankton net (mesh size $35 \mu \mathrm{m}$ ) and fixed in $4 \%$ formalin, before being analyzed under a microscope (at 10-20×) in $0.5 \mathrm{ml}$ chambers. Numerical analyses were as followed by Wetzel (1975).

Some physical and chemical characteristics of the water were also studied to assess the impact of abiotic factors on the dynamics of $N$. squamula salina. The collection of water samples was immediately followed by laboratory measurements of: salinity, conductivity and TDS (total dissolved solids) using an LF-197 conductometer from WTW, Wilheim, Germany; and pH using an HI 9025
Fig. 1 Location of Lake Wujka and of sampling points (Sp 1, Sp 2)

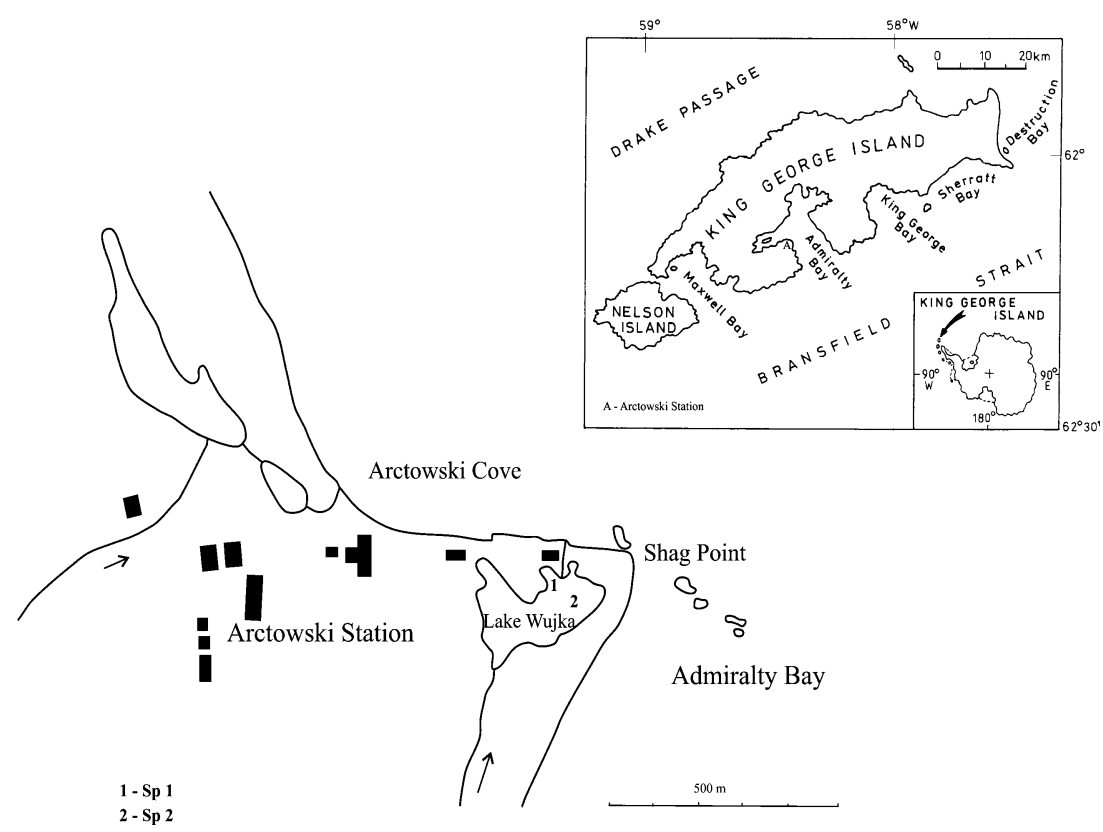


pH-meter from Hanna Instruments. Water temperature was measured in situ at $\mathrm{Sp} 1$ and $\mathrm{Sp} 2$ with a mercury thermometer.

Spearman's non-parametric correlation coefficient was computed (SPSS for Windows Version 11.5.0.), in order to identify possible influences on the dynamics of $N$. squamula salina.

\section{Results}

The two sampling points in Lake Wujka differed in physical-chemical characteristics (Table 1). Sp 2 was cooler and more saline than $\mathrm{Sp} \mathrm{1.} \mathrm{Usually,} \mathrm{pH}$ values were similar, but salinity, TDS and conductivity varied between the sites, probably due to influx of melted water and spray from the sea.

During the investigated period, the Lake Wujka was icefree from 29th December to 7th April; from 22nd November to 28th December and from 8th April to31st of May, only the surface was covered with ice (thickness of ice 2-60 cm). But between 1st June and 7th October, the lake was frozen from the surface to the bottom.

Rotifer densities were also different between Sp 1 and Sp 2. The maximum density at Sp 1 was 114 ind. $1^{-1}$ in June, following a storm and with the water saline. At other times the population tended to remain below 25 individuals $1^{-1}$. At $\mathrm{Sp} 2$, the two highest density peaks were noted in January (80 ind. $1^{-1}$ ) and May (150 ind. $1^{-1}$ ). At the former site there were several peaks of over 40 ind. $1^{-1}$ (Fig. 2).

Spearman's correlation coefficient between water quality factors and $N$. squamula salina densities revealed that at Sp 1, N. squamula salina densities were inversely correlated with TDS and $\mathrm{pH}$, while the remaining factors were non-significant. TDS and $\mathrm{pH}$ were influenced directly, since these are not correlated with each other (Table 2). At Sp 2, all correlations between rotifer densities and physical-chemical variables except TDS were significant. While temperature and $\mathrm{pH}$ correlated inversely with population density, salinity and conductivity were correlated with it directly. These parameters showed an indirect impact, correlated with each other (Table 2).

\section{Discussion}

Coastal lakes, shallow and polymictic, are a mosaic of habitats characterized by species poverty and dominated by species resistant to changing environmental conditions (Paturej 2006). Lake Wujka is such a coastal lake, with a zooplankton strongly affected by rapid fluctuations in

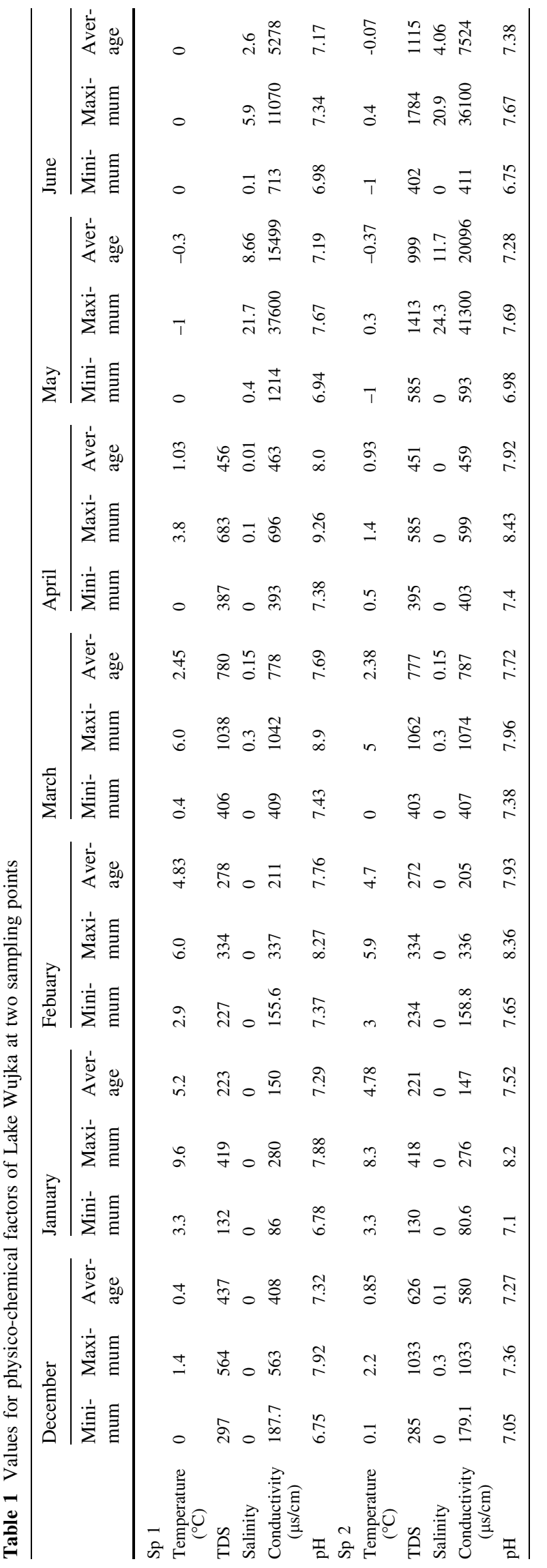




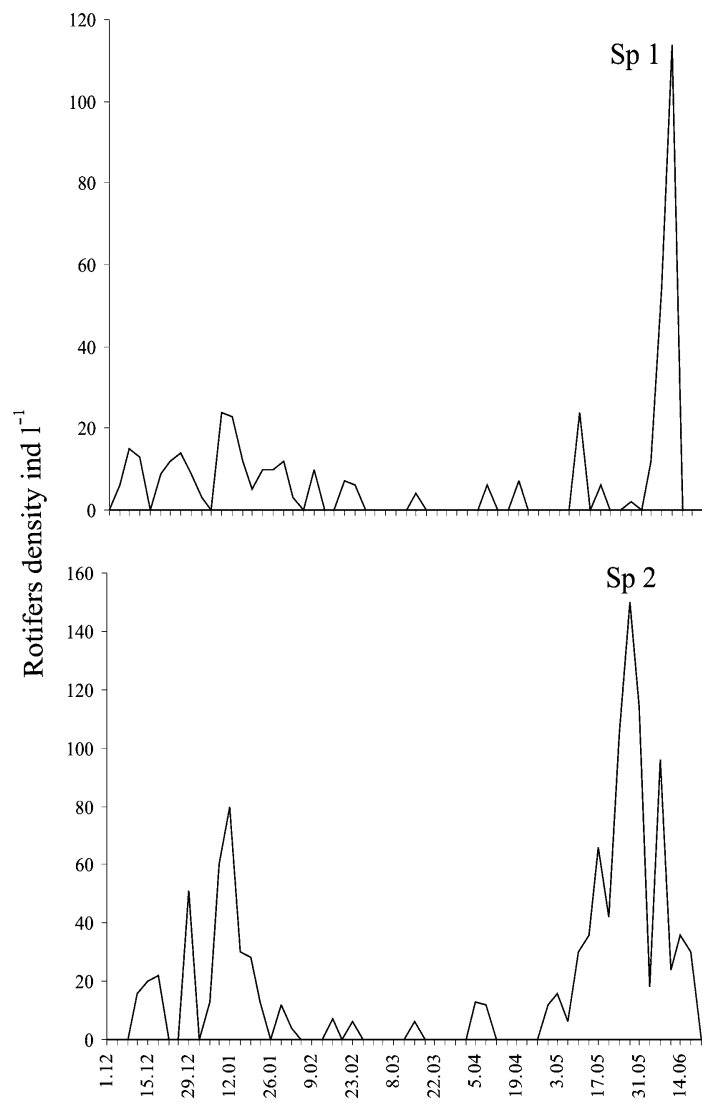

Fig. 2 Dynamics of $N$. squamula salina at points 1 and 2 in Lake Wujka (December-June) abiotic factors such as time- and space-related salinity, temperature, oxygen saturation, nutrient availability and wave motion. These factors influence species composition, densities and biomass. N. squamula salina has a clear preference for saline water (Hart et al. 1991; Fontaneto et al. 2006). It survives the freshwater phase of Lake Wujka, but thrives when seawater enters during storms, and salinity is significantly correlated with the density of the rotifer. Also, high densities after storms probably are connected with rotifer behavior. $N$. squamula salina lives preferentially at the bottom. However, during storm and strong winds, Lake Wujka is mixed and stirs up bottomliving rotifers to the open water where they remain there for a while.

Janiec (1996) showed that $N$. squamula salina is dominant in ponds and in the littoral zone of ponds influenced by the salt (Janiec 1993). In turn, the deep (23 m), saline and meromictic Ace Lake had low numbers of Notholca (6 ind. $\mathrm{l}^{-1}$ ) at a depth of $6 \mathrm{~m}$. The plankton of Ace Lake was dominated by microbial plankton, with small numbers of metazoa (Bell and Laybourn-Parry 1999). It follows that salinity is not the only factor, as lake depth may also have a role to play.

According to Hart et al. (1991), many Rotifera have a tolerance to salinity, albeit with the greatest diversity of species in waters of salinity $400-1,000 \mathrm{mg} \mathrm{l}^{-1}$, and some species living in lakes with salinities from 400 to $8,000 \mathrm{mg}^{-1}$ (e.g., Brachionus plicatilis). In Lake Wujka,

Table 2 Spearman coefficients between densities of $N$. squamula salina at Sp 1 and Sp 2 and physical-chemical factors

\begin{tabular}{|c|c|c|c|c|c|c|}
\hline Parameter & Rotifer density & Temperature & TDS & Salinity & Conductivity & $\mathrm{pH}$ \\
\hline \multicolumn{7}{|c|}{ Rotifer density } \\
\hline Sp 1 & - & - & - & - & - & - \\
\hline Sp 2 & - & - & - & - & - & - \\
\hline \multicolumn{7}{|l|}{ Temperature } \\
\hline Sp 1 & ns (54) & - & - & - & - & - \\
\hline Sp 2 & $-0.437 * *(56)$ & - & - & - & - & - \\
\hline \multicolumn{7}{|l|}{ TDS } \\
\hline Sp 1 & $-0.415 * *(47)$ & $-0.628 * *(47)$ & - & - & - & - \\
\hline Sp 2 & ns (47) & $-0.659 * *(47)$ & - & - & - & - \\
\hline \multicolumn{7}{|l|}{ Salinity } \\
\hline Sp 1 & ns (54) & $-0.551 *(54)$ & $0.715 * *(47)$ & - & - & - \\
\hline Sp 2 & $0.442 * *(56)$ & $-0.691 * *(56)$ & $0.788 * *(47)$ & - & - & - \\
\hline \multicolumn{7}{|c|}{ Conductivity } \\
\hline Sp 1 & ns (54) & $-0.741 * *(54)$ & $0.983 * *(47)$ & $0.823 * *(54)$ & - & - \\
\hline Sp 2 & $0.269 *(56)$ & $-0.781 * *(56)$ & $0.980 * *(47)$ & $0.881 * *(56)$ & - & - \\
\hline \multicolumn{7}{|l|}{$\mathrm{pH}$} \\
\hline Sp 1 & $-0.314 *(54)$ & $0.268 *(54)$ & ns (47) & ns (54) & ns (54) & - \\
\hline Sp 2 & $-0.506 * *(56)$ & $0.458 * *(56)$ & ns (47) & $0.309 *(56)$ & ns (56) & - \\
\hline
\end{tabular}

$n s$ not significant

* $P=0.05$

** $P=0.01$ 
$N$. squamula salina was found at salinities of 47328,084 $\mathrm{mg} \mathrm{l}^{-1}$ (Pociecha, unpublished data).

Temperature too plays a role. Its effect was significant at Sp 2, while at Sp 1 TDS influenced the density of $N$. squamula salina, again connected with a stirring up of the bottom sediments. The density of Notholca also depended on food concentration. May (1980) showed that $N$. squamula occurred at temperatures below $10^{\circ} \mathrm{C}$, when the density of the diatom Asterionella formosa was high. The diatom community in Lake Wujka had diatoms in the same class size, e.g., Achnanthes lanceolata var. rostrata, at a percentage share of $49.71 \%$. Phytoplankton density at Sp 2 ranged from 66,000 cells $1^{-1}$ in Decem-

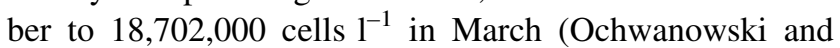
Pociecha 2005). Ample food was therefore available for rotifers at a time when water temperature did not exceed $10^{\circ} \mathrm{C}$ and turbulence was high.

My field study shows that a low temperature, even below $0^{\circ} \mathrm{C}$, combined with a salinity of more than $20 \mathrm{psu}$, stimulates $N$. squamula salina. This suggests that in this species, low temperature and high salinity induce a very quick egg development, a hypothesis that should next be verified in laboratory conditions.

On the other hand, the density of diatoms in Lake Wujka also was impacted by salinity (Ochwanowski and Pociecha 2005). The dominant diatom that Notholca probably eats is benthic. When a storm occurs, it brings seawater and turbulence to the lake, and this stirs up the diatom. This, in its turn, stimulates the rotifer's development.

To understand the high density of $N$. s. salina in harsh environmental conditions, we need also to recognize diapause and dormancy patterns of this rotifer species, because environmental factors control resting egg hatching and affect resting egg survival (see: Ricci 2001; Schröder 2005).

In addition, the species is probably capable of surviving in a wide range of aquatic environments, including freshwater. The ability of this rotifer to do this is extremely important since it may be capable of waiting for the right circumstances to quickly unfold its potential.

Acknowledgments I thank Prof. H. Dumont for his critical opinion regarding the text and language correction, and Prof. S. RakusaSuszczewski for enabling me to participate in the 28th Polish Antarctic expedition to the $\mathrm{H}$. Arctowski station. My study was supported by the State Committee for Scientific Research based in Warsaw, grant PBZ -KBN-108/PO4/2004.

\section{References}

Bell EM, Laybourn-Parry J (1999) Annual plankton dynamics in an Antarctic saline lake. Freshw Biol 41:507-519

Camacho A (2006) Planktonic microbial assemblages and the potential effects of metazooplankton predation on the food web of lakes from the maritime Antarctica and sub-Antarctic islands. Rev Environ Sci Biotechnol 5:167-185

Dartnall HJG (1983) Rotifers of the Antarctic and subAntarctic. Hydrobiologia, 104:57-60

Dartnall HJG, Hollowday ED (1985) Antarctic rotifers. Br Antarct Surv Sci Rep, 100:46

Fontaneto D, De Smet WH, Ricci C (2006) Rotifers in saltwater environments, re-evaluation of an incospicous taxon. J Mar Biol Ass UK 86:623-656

Hart BT, Bailey P, Edwards R, Hortle K, James K, McMahon A, Meredith Ch, Swadling K (1991) A review of the salt sensitivity of the Australian freshwater biota. Hydrobiologia 210:105-144

Janiec K (1993) The freshwater micro- and meiofauna of Admiralty Bay, King George Island, South Shetland Islands: proceedings of NIPR symposium. Polar Biol 6:133-138

Janiec K (1996) The comparison of freshwater invertebrates of Spitsbergen (Arctic) and King George Island (Antarctic). Pol Polar Res 17(3-4):173-202

May L (1980) On the ecology of Notholca squamula Müller in Loch Leven, Kinross, Scotland. Hydrobiologia 73:177-180

McInnes SJ, Ellis-Evans JC (1990) Micro-invertebrate community structure within a maritime Antarctic lake: proceedings of NIPR symposium. Polar Biol 3:179-189

Ochwanowski P, Pociecha A (2005) The impact of abiotic factors on diatom density dynamics in the freshwater lake Wujka near the Henryk Arctowski Polish Antarctic station during austral summer. Oceanol Hydrobiol Stud 34(Supplement 3):257267

Paturej E (2006) Assessment of the trophic state of the coastal Lake Gardno based on community structure and zooplankton-related indices. Electronic Journal of Polish Agricultural Universities: http://www.ejpau.media.pl/volume9/issue2/art-17.html

Pejler B (1995) Relation to habitat in rotifers. Hydrobiologia 313:267-278

Pociecha A (2005) Effect of temperature on respiration of Branchinecta gaini (Daday, 1910). Abstracts SEFS 4-4th symposium for European Freshwater Sciences, Kraków, 22-26 August 2005, p 128

Rakusa-Suszczewski S (1992) Zatoka Admiralicji. Antarktyka, Oficyna Wydawnicza. Instytut Ekologii PAN, Dziekanów Leśny pp 9-13

Ricci C (2001) Dormancy patterns in rotifers. Hydrobiologia 446/ 447:1-11

Schröder (2005) Diapause in monogonont rotifers. Hydrobiologia 546:291-306

Swadling KM, Dartnall HJG, Gibson JAE, Saulnier-Talbot E, Vincent WF (2001) Fosill rotifers and the early colonization of an Antarctic lake. Quat Res 55:380-384

Wetzel RG (1975) Limnology. Philadelphia-London-Toronto. W. B. Sounders, $743 \mathrm{pp}$ 